\title{
中山第一コークス爐の築造, 乾燥及び
}

\section{スタート作業}

株式會社中山製鋼所コークス課長 大 樂 恭知

\begin{tabular}{|c|c|c|}
\hline & 目。次 & [3] 乾燥作業 (A) \\
\hline$[1]$ & 言 & [4] 乾燥作業 (B) \\
\hline 〔2] 软 & 設 & [5] スタート作業 \\
\hline
\end{tabular}

\section{〔1〕緒帝}

昭和 11 年中山製鋼所か銑鋼一貫作業の目的飞向つて熔鑛㠠の建設を計畫すると同時に，乙 れにコークスを供給する妥めコークス盧の建設を灶定した。盧は黑田複式コークス盧で，現在 は1基のみであるか，更に同樣なものを1基建設する祲定てある。

設計圖は日本骸炭战株式會社より供給を受け當所建設部にて，中島部長，大《顧問を中心に 配置築造したものてある。盧の概要を示すと第1表の通りてある。

第 1 表爐 の 溉 要

\begin{tabular}{|c|c|c|c|c|}
\hline 㲾 & 數 & 55 䇪 & 窒 & 55 窯 \\
\hline \multirow{2}{*}{ 一 } & \multirow{2}{*}{$\begin{array}{l}\text { 幅 }(\mathrm{mm}) \\
\text { 長 } \\
\text { 高 }\end{array}$} & \multirow{2}{*}{$\begin{array}{r}12,400 \\
63,730 \\
9,690\end{array}$} & 燃 燒 室 數 & 30 室 \\
\hline & & & 各盧中心距離 (mm) & 1,100 \\
\hline \multirow{3}{*}{ 炭 化 室 } & (幅 $(\mathrm{mmit})$ & $380 \sim 420$ & \multirow{3}{*}{ 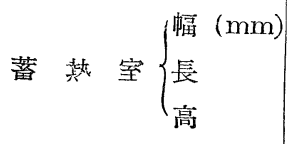 } & 740 \\
\hline & 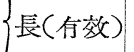 & 11,790 & & 5,282 \\
\hline & (高( " ) & 3,550 & & 3,270 \\
\hline \multicolumn{2}{|c|}{ 一窒裝炭量( 乾炭) $(\mathrm{kg})$} & 13,200 & 洷通斷面樍 $\left(\mathrm{nl}^{2}\right)$ & 272 \\
\hline \multirow{3}{*}{ 燃 燒 墪 } & (幅 $(\mathrm{mm})$ & 500 & \multirow{3}{*}{ 症 突 $\left\{\begin{array}{l}\text { 高 }(\mathrm{mm}) \\
\text { 内徍 }\left\{\begin{array}{l}\text { 上 } \\
\text { 下 }\end{array}\right.\end{array}\right.$} & 80,000 \\
\hline & $\{$ 長 & 265 & & 3,000 \\
\hline & 高 & 3,500 & & 5,200 \\
\hline
\end{tabular}

盧は勿論高盧ガスを使用し得る樣となつてわるか，現在はコークス盧かスのみを用ひてみ る。建設敷地は，木聿川本流と運可の分肢坫の三角形の陝い地帶て，乙れに熔鑛盧 2 基, コ一 クス盧 2 基並に之等に附屬する諸工場—ニークス盧關係ては先炭工場，硫安工場，ヘンッー 儿工場等全部建てられて居り 其の孚め各工場の配置には苦心か拂はれて居る。 


\section{第 2 表 建 設 日 程}

\begin{tabular}{|c|c|c|c|}
\hline 年 & 月 & 日 & 建 設 事 項 \\
\hline \multirow[t]{2}{*}{ 昭和12 } & 2 & 28 & 地 镇 祭 \\
\hline & 8. & 10 & 基礎工事着手 \\
\hline \multirow[t]{3}{*}{ 昭和13 } & 1 & 24 & 痓道煉瓦積開始 \\
\hline & 5. & 28 & 同上終了 \\
\hline & 6 & 2 & 爐䯤煉瓦積開始 \\
\hline \multirow[t]{3}{*}{ 昭和14 } & 1 & 18 & 同上終了 \\
\hline & 3 & 19 & 乾燥作業着手 \\
\hline & 7 & 12 & 作 業 閭 始 \\
\hline
\end{tabular}

第 3 表 煉瓦使用策所

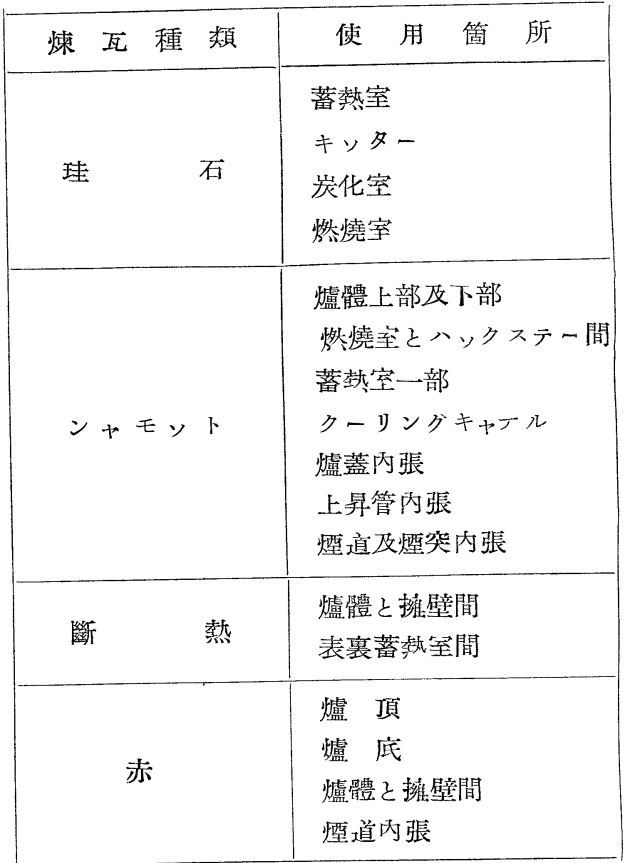

[2]建

設

建設日程は第 2 表の通りで，基礎工事着手 後 1 年 11 万月てスタートした事になる。

敷地の土質は軟弱であり，且つ高潮の來襲 飞備へるへく筀道の底部をクラントラインの 上飞置いた管め基礎工事並に土木工事に日數 を要した。爐體梀瓦積は2 55 日か小つてるる が，乙れは运中涑瓦の製造が掘れたり，又運 搬船の况秫等の事故て，約 2 万月間は工事を 殆に゙中止する狀態が續いた故である。

築造に使用した煉瓦は，珪石，シャモット， 斷熱，赤の 4 種類て，其の使用箇所は第 3 表 の通りてある。使用煉瓦類の品質及び使用量 等は，第 4 表の通りてある。但し，表中には 厔道，煙突の分は含ます，又斷熱煉瓦中には， 粒狀の为のを含んてるる。使用延人員は第 5 表の通りである。

爐體築造時飞之りたる膨脹目地代は，各筧 に付を，蓄熱室の部分では $10 \mathrm{~mm}$ それより 上方部にては，10〜20 $\mathrm{mm}$ をとり，是等は充 分飞掃除を妥し，輕く薆繩を詰めて，順次上 段に積んて行つた。又炭化室底部の目地は外 部之通じて居る關係上オカクズを充填した。 爐體と擁壁の赤梀瓦間には $100 \mathrm{~mm}$ の間隙

第 4 㤗使 用材料

\begin{tabular}{|c|c|c|c|c|c|}
\hline 名 & 稱 & 種 & 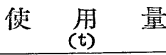 & 品 & 製 造 元 \\
\hline \multirow[t]{2}{*}{ 煉 } & \multirow[t]{2}{*}{ 瓦 } & 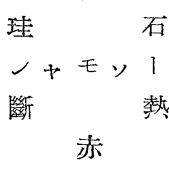 & $\begin{array}{r}6,699 \\
2,386 \\
24 \\
635\end{array}$ & 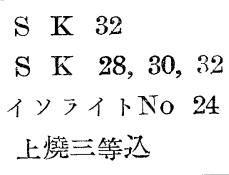 & $\begin{array}{l}\text { 黑崎窂業 } \\
\text { 黑崎及阪窯業 }\end{array}$ \\
\hline & & 計 & 9,744 & & \\
\hline \multirow{2}{*}{\multicolumn{2}{|c|}{$モ ル タ ル$}} & 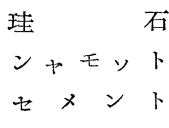 & $\begin{array}{r}805 \\
292 \\
35\end{array}$ & $\begin{array}{lll}\mathrm{S} & \mathrm{K} & 32 \\
\mathrm{~S} & \mathrm{~K} & 28,30,32\end{array}$ & $\begin{array}{c}\text { 黑崎篹業 } \\
\text { " } \\
\text { 大阪董業 }\end{array}$ \\
\hline & & 計 & 1,132 & & \\
\hline
\end{tabular}


第 5 表使 用人 員

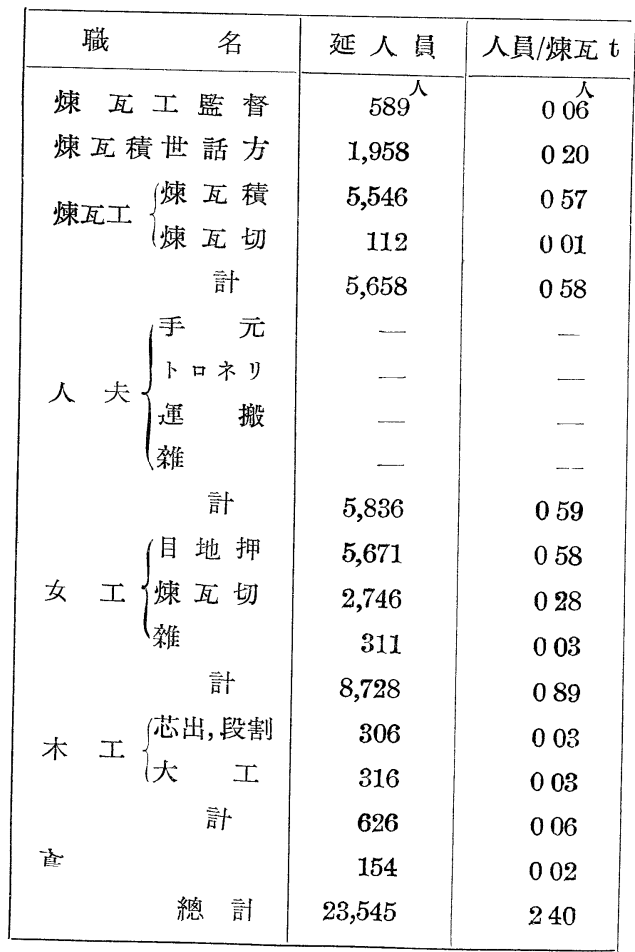

を設けて，てれルは斷埶煉瓦及び粒を充填し た。膨脹と對する其他の設備としては，爐底 シャモット煉瓦の 2 段目と 3 段目間に 24 番 の黑鈑 3 枚を幅 $2,600 \mathrm{~mm}$ に表裏各一列バ, クステーに近き端に敷き，之りの役目をさせ た。又燃燒室とバックステー閒には厚さ $8 \mathrm{~mm}$ の鐵鈑を挾み，同樣之りの役目をさした。分 配本管とガス水平煙道間の炣口管は鉛管を使 用した。ステーホルトにはスプリンクを大れ る豫定てはあつたか，スプリンクの製作が間 に合はす，止むなく木を用いた。表裏プラッ トフォームは支柱の足のアンカーボルト穴を 細長く作り，乙れを移動し得る樣にした。

\section{[3] 乾燥作業 $(\mathrm{A})$}

乾燥作業は言ふ迄子なく，煉瓦を乾燥させ て，爐體を作業愠度まて，師ち約 $900{ }^{\circ} \mathrm{C}$ 以 上飞加熱して，スタートの場合力ス鲇火に差 支へない樣とするものてある。其の段階は煉互の乾燥される時期, 急激なる膨脹の起る時期及 ひ爐體を作業温度まて加熱する時期の 3 期をとるものてある。元來，爐體の大部分を形成して るる珪石梀瓦は，熱間耐壓，熱傳導率等に於ては優秀てあるか，熱の急變に弱い事と，石英の 轉位性等の孚め，加熱膨脹率が著しく大て且つ不均一てある。是等の缺跕を避ける孚には，乾 燥作業は，各爐の温度を出來るだけ均一にし，溫度上昇を徐々になし，膨脹を均一且つ直線的 に起らせる事か必要てある。加卦方法は分スを使用するの便利てあるか，當所には其の設備 なき故，石炭々依つた。石炭焚の孚め煙道及び各炭化室の表裏に第 1 圖及ひ第 2 圖の如き乾燥

\section{第 1 圖煙道乾燥爐}

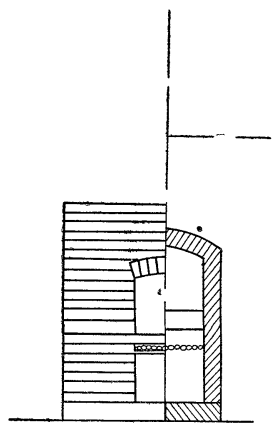

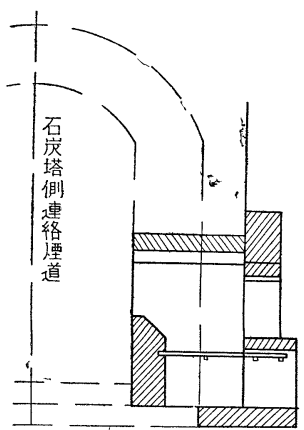

假盧を築いた。

當所歷道は石炭塔側にて，表裏連絡して居

り，乾湂焚口は此の中閒に設けた。爐室乾燥 假盧は，炭化室棟瓦と假爐梀瓦の接觸部分は モルタルを用ひ亦，又煉瓦相互閒のモルタル 粘土粉を練つて用ひ，取壞しに便利な樣に した。押へ煉瓦は修理しを假盧のものには， 凸部のある为のを使用した。三つの口の內 1 より石炭を裝入し， 3 より灰を取り出す。 2 はダンパー及ひ內部の石炭を搔き趩す役目に用ひた。此の外炭化室底部に乾喿孔 2 筒を設け， 
第2圖爐室乾蜗假爐
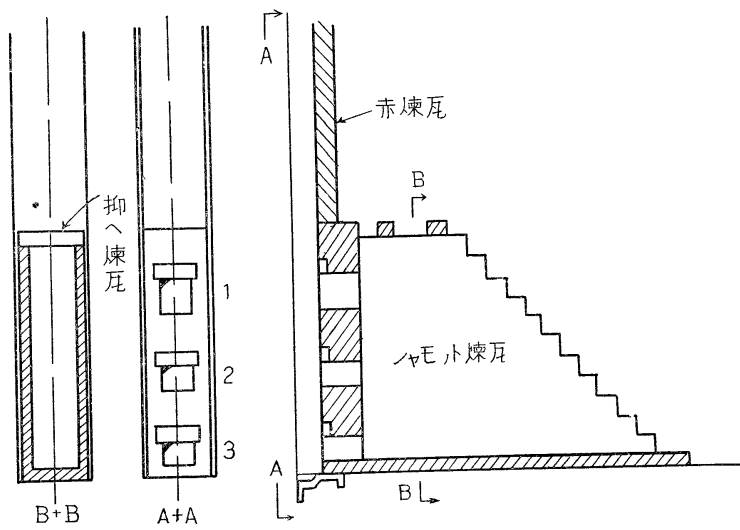

表裏蓄熱室と連絡させ, 又炭化室上 部に，2 皮ひ 29 番燃燒室と連絡す る孔を各 1 䇢設けた。 加埶用燃料は薪，コークス及び石 炭て、コークスは筀道用に用ひた。 石炭は如何なるものを用ひるかは可 成り問題て，當所としては矢の㨾な 標隼を立てた。郎ち石炭は乾澡中ク リンカーを生して，盧體の梀瓦を傷 めをり，通風を阻害したりする事を 防ぐへく，粘結性のないもの，灰分

は少く $10 \%$ 以下のもの，灰の熔融高く $1300^{\circ} \mathrm{C}$ 以上の多の，發熱量は高く $7000 \mathrm{cal}$ 以上の\& のて，且つ焚き易い拿め塊丈は中塊とした。實際使用した石炭は，主として高松中塊炭て， 此の外少量の䍏順炭及ひ早良炭てある。早良炭は不向てはあつたか，止むなく使用したもので ある。

愠度則定には，常温より $300^{\circ} \mathrm{C}$ 附近迄は水銀塞暖計，それ以上 $450^{\circ} \mathrm{C}$ 位迄は窒素大水銀 寒暖計，更にそれ以上はサーモパイロメーター，更に高慍ては光學及ひ輻射高愠度計を併用し た。

則定の䇢所は第 6 表の通りて，乙れを午前，午後及び夜間 2 回，計 1 日 4 回則定した。 爐體の温度は燃燒室 60 箇所の平均值を以つてした。

第 6 表 溫度測定箇所

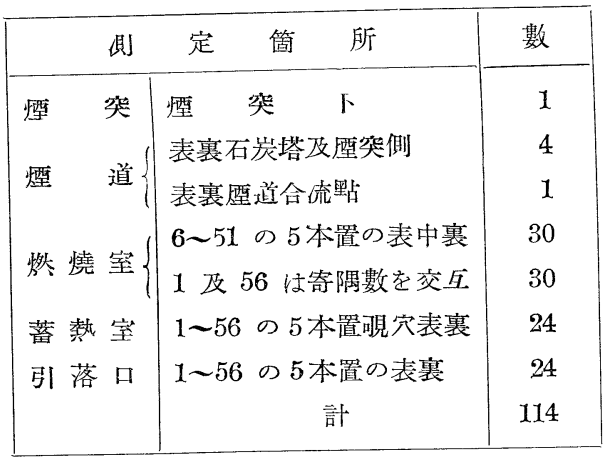

第3 圖 幅 膨脹測 定 法

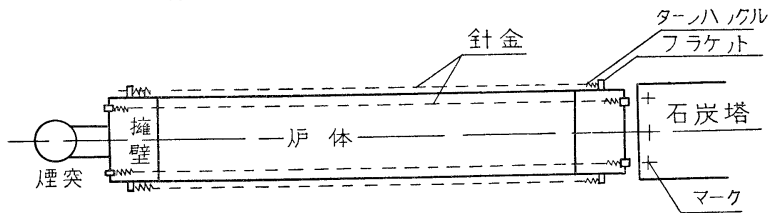

トラフトは第 7 表の如を箇所を測定した。

第 7 表 トラフト測定箇所

\begin{tabular}{|c|c|c|c|c|}
\hline & 即 & 定 & 䈪 & 數 \\
\hline 煙 & 突 & $\begin{array}{l}\text { 煙 } \\
\text { 表裏石 }\end{array}$ & $\begin{array}{l}\text { 突 下 } \\
\text { 炭塔及曆突側 }\end{array}$ & $\begin{array}{l}1 \\
4\end{array}$ \\
\hline 㭫 & 㨁 & $\begin{array}{l}\text { 大ダン } \\
\text { 表裹輏 }\end{array}$ & 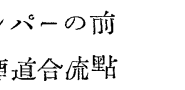 & $\begin{array}{l}2 \\
1\end{array}$ \\
\hline 引 落 & & $1 \sim 56$ & $\begin{array}{c}\text { の } 5 \text { 本置表裏 } \\
\text { 計 }\end{array}$ & $\begin{array}{l}24 \\
32\end{array}$ \\
\hline
\end{tabular}

膨脹の則定は，石炭塔橫手飞さ いはひ深さ 600 尺の鳘井あり，此 のパイプに原坫をとり，てれより 石炭塔上に移し，更に推壁上飞移 、してマークを附す。

幅の則定は第 3 圖に示す如く，爐頂ては表裏と 2 本の針金を擁壁間に張り，此の針全と爐項 
の端の間隔を測定する。猶針金はをるむのを防ぐ蛍め爾端にターンバックルを附して締める樣 にした。蓄埶室上部及ひ爐底子同樣に擁壁支桂にフラケットを固定して，てれに針金を張つて 測定する。以上を 1〜56 番の燃燒室及ひ蓄熱室の內 5 本置きのものと就て行つた。

長さの側定牥，第4 圖の如く盧頂に於ては 1 56 番の燃燒室の內 5 本置きの 8 の表中裏

第4圖 長 膨 脹 測 定 法

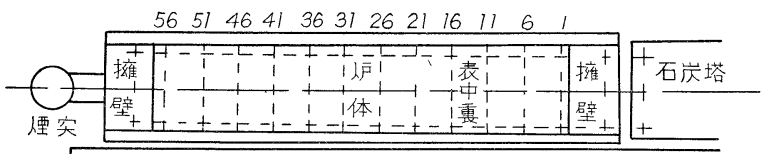

十 押出機フラハフオーム

十印原虫マーク と夫ぞ線を引き，擁壁上のマークよ り則定する。蓄熱室上部及ひ爐底は 1〜56 番の蓄熱室を擁壁支柱のマー クより則り，其の他は便宜上バック ステーよりの移動長さを則つた。

高さの測定は爐上のマークに垂直 棒を立て，石炭塔にトランシットを据急て則定した。てれは 1 週閒に 1 回行つて，每日の目安 はバックステーに印を附けて置を，てれと爐頂閒の距離を則り，ハックステー自身の持ら上げ られを距離を則つて補正したものを以つてした。

以上各部の則定を 2〜4 日に 1 回行ひ，擁壁上マークの補正及び石炭塔疒下に低る補正は 1 週間に 1 包行つそのてある。厔突側擁壁のマークは押出機プラ,トフォーム上の原坫より補 正した。

\section{〔4〕乾 燥 作 業 $(\mathrm{B})$}

實際の作業結果を纒めて見ると愠度上景其の他は第5 圖の通りてある。

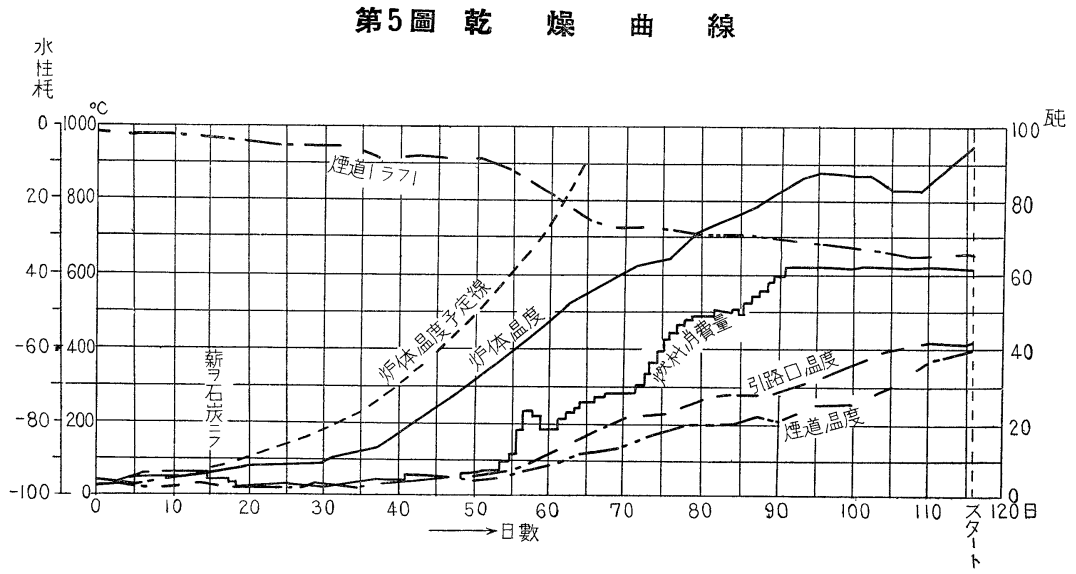

乾燥日數は，70日を豫定して居たか土事の掘延の妥め116日になつた。

加熱は煙笑，煙道，爐體を同時に開始した。煙突は薪を積み，乙れに點火後直ちにマンホー ルを煉瓦でつぶす。煙道を焚くのは乾燥より寧ろトラフトをつける意味である。爐體假爐より の加熱潅は

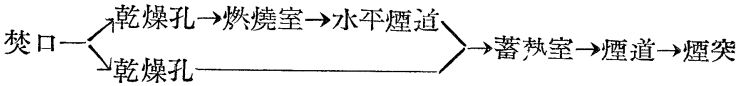


の如き通路を辿る。最初水分の蒸發盛んを時期は，然熱室の各覘穴の蓋を取つて，てょより外 部に發散さす。17日目より切換を開始し最初は 4 時間，順次 2 時間，1 時間，30 分と切換 時間を短縮して行く。 $500^{\circ} \mathrm{C}$ 位より燃鹿室底部が赤くをつて來る。 $800^{\circ} \mathrm{C}$ 近くから楚口にクリ ンカーか生し始め, 又假盧の壞れるものもあり, 嗢度上景が豫定通り進み難くなり, スター下 迄飞は $1000^{\circ} \mathrm{C}$ に上昇させる豫定か，透に $940^{\circ} \mathrm{C}$ 迄しか上景せしめ得なかつた。

トラフトは最初思ふ樣につかす，途中 2 包多焚直し，石炭を楚き始めてより 10 日目位より 漸く所期のものになり，20 日目位より煙道の温度も上泉し始めた。此の 2 回の焚直しは最初

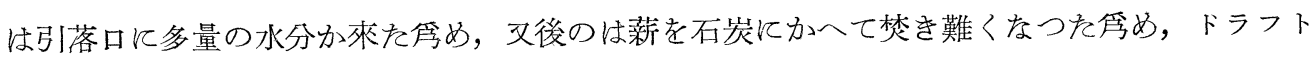
汃下した故てある。

爐體加熱の燃料は最初は薪を焚き 23 日目より石炭に代へた。是等の燃料は 1 盧當りの使用 量を科量して各盧飞配給し，一定時 第 6 圖 各 部 溫度 閒內に焚玑し，温度の均一になる事 を期した。消費量總計は第 8 表に示 す通りてある。

\section{第 8 表 燃料消費量}

\begin{tabular}{|c|c|c|c|}
\hline & 获 & コークス & 石 炭 \\
\hline 凐 突 & 110 & $\underline{\mathrm{kg}}$ & $\mathrm{kg}$ \\
\hline 酎 道 & 4,640 & 2,960 & 8,100 \\
\hline 爈 體 & 90,615 & - & $2,999,442$ \\
\hline 計 & 95,365 & 2,960 & $3,008,542$ \\
\hline 1 篓富 & 1,647 & - & 54,535 \\
\hline
\end{tabular}
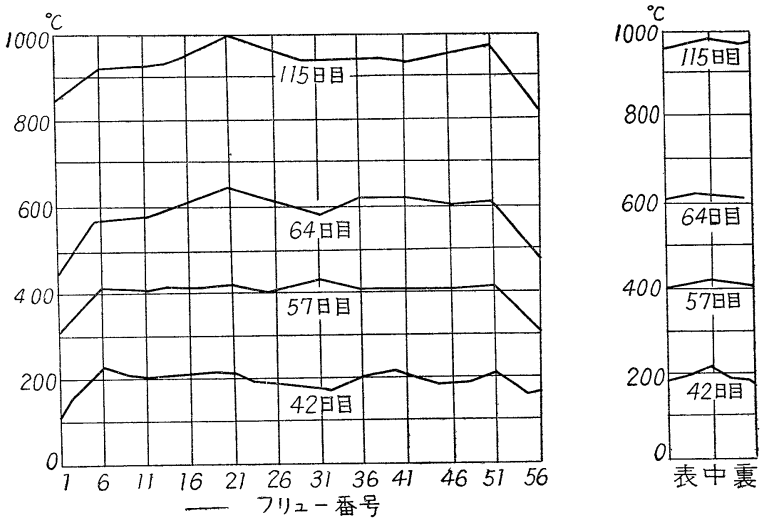

猶, 乾喿中各盧, 各部の温度が均一になる樣に, 第 6 圖の如きクラフを描き，乙れに依り 燃料の調節其の他を行つた。

此の圖を見ると大體温度は均一に上昇してるるが，只端窒が他のものに比較して約 $100^{\circ} \mathrm{C}$ 近くも低くなつた。勿論てれは最初より豫想して居えのて，焚方等に就き端空は特別に军を付

第 7 圖 膨 脹 曲 線

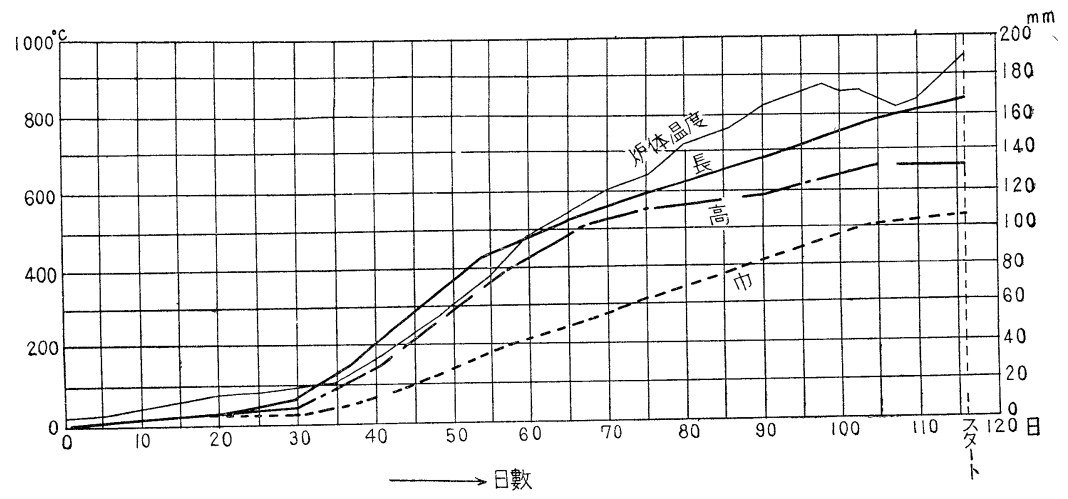


第8圖各 部 膨 脹 (幅)

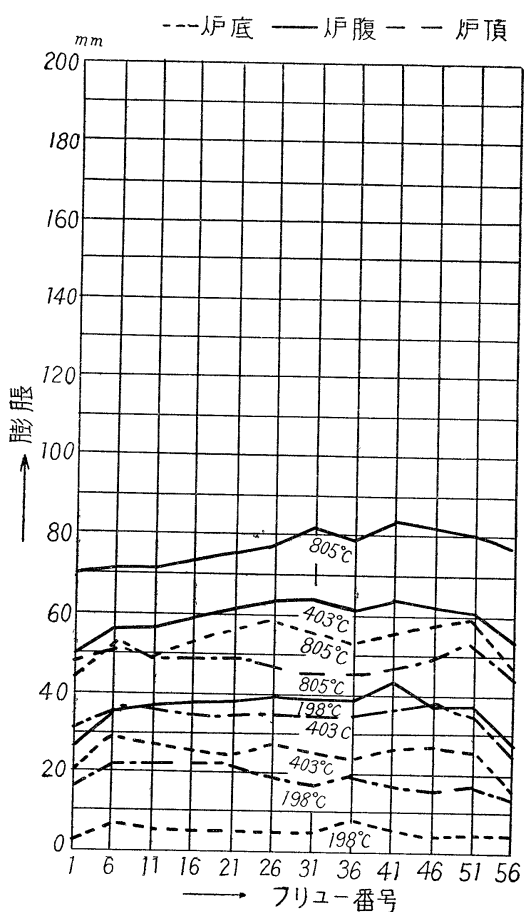

第 9 圖 各部膨脹(長)
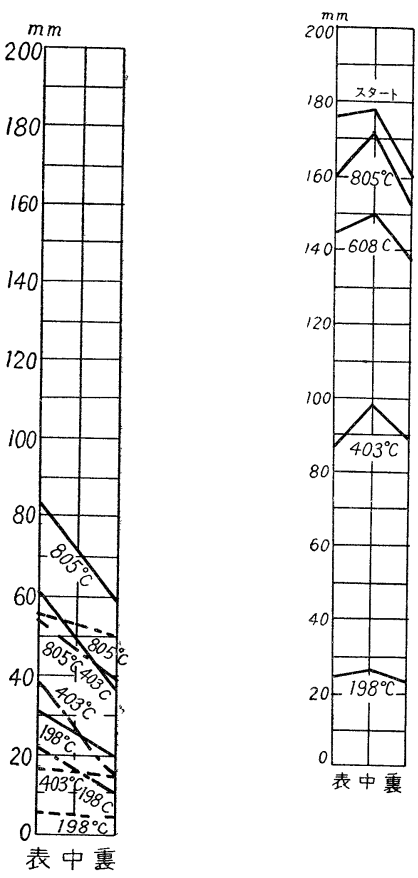

第 10 圖 膨脹曲 線 圖 (高)
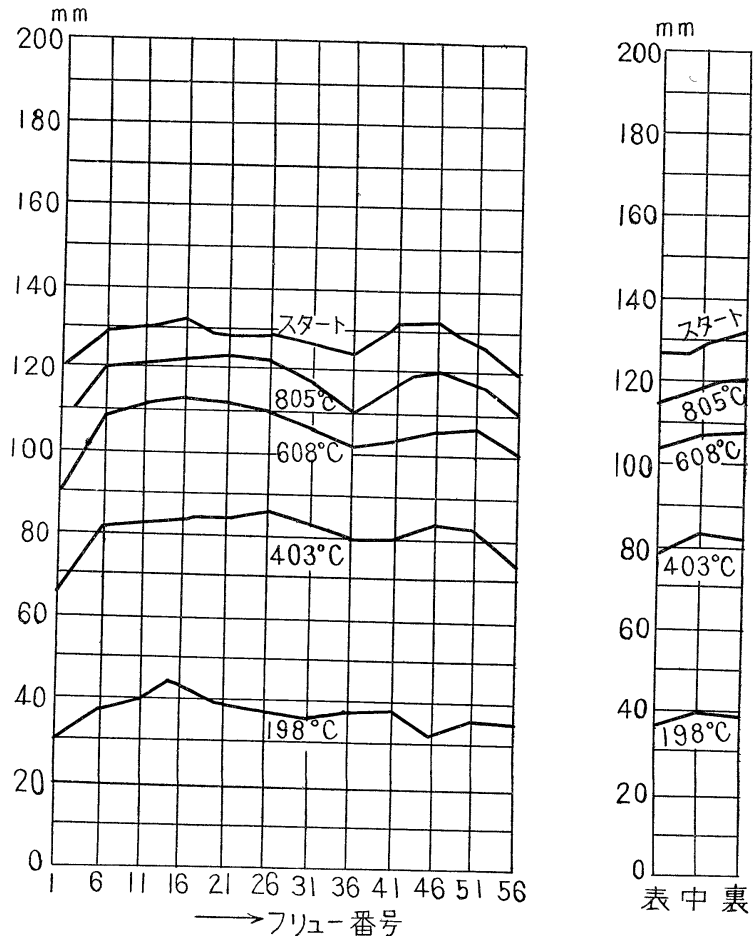
けたのてあるか，同し柱にならなかつた。乾燥の終期に於て，クーリーグキャナルの保護板の 部分を充分崟りつぶしたか，乙れは相當有效と思はれた。

膨脹は乾懆開始後 2 週間目より則定した。結果は第 7 圖の如く $100^{\circ} \mathrm{C}$ 附近より $700^{\circ} \mathrm{C}$ 附 近の間て急激に膨脹してるる。各爐各部の膨脹は第 8 圖〜第 10 圖の如くてある。

第9表 ステーホルト弛め方

\begin{tabular}{|c|c|c|}
\hline & ${ }_{(\text {回 })^{\text {數 }}}$ & 長 \\
\hline \multirow{2}{*}{ 爐 頂 } & 10 & 43 \\
\hline & 1 & 6 \\
\hline \multirow{2}{*}{ 爐 底 } & 2 & 17 \\
\hline & 2 & 18 \\
\hline
\end{tabular}

幅方向に就ては爐媔部に於て，シャモ，下煉瓦の膨脹係數 か珪石凍瓦のそれに比校して小なる孚め珪石梀瓦の膨脹につ れて外方に引張られ，裝大口煉瓦に目地切を生した。てれは 布を張りコールターを荃布して币水を防を，乾燥終期飞目塗 りをした。ステーボルトのナ、トは第 9 表に示す如く弛めた 汃，毫側はトライメイン取付工事の孚め，弛め方か少く爐頂

部は表側より大と膨脹した。

爐底に敷いたえり板は爐底の幅膨脹小なる蛍めか，期待しを程の效果はをい樣てあつを。

長さ方向に對しては, 爐體と擁壁間のイソライトか力外部に押し出されたのて, 乾燥後赤煉瓦を 積んて修理した。又各爐の中心か左右の兩擁壁に向つて移動し, 特に端に於て著しく, 其の測定 結果は第 10 表に示す通りてある。此の孚め犲口管か押潰されガスの漏㖂甚たしかつたのて，

第 10 表 フリュー中心線の移動

\begin{tabular}{|c|c|c|c|c|c|c|c|c|c|c|c|c|c|}
\hline エリ番 & 1 & 6 & 11 & 16 & 21 & 26 & 28 & 31 & 36 & 41 & 46 & 51 & 56 \\
\hline 䔟 $\left\{\begin{array}{c}\text { 表 } \\
\text { 寒 }\end{array}\right.$ & $\begin{array}{c}(\mathrm{mm}) \\
84\end{array}$ & 66 & 49 & 35 & 21 & 7 & 0 & 7 & 20 & 34 & 48 & 65 & 82 \\
\hline
\end{tabular}

第11表 辻り钣及バックステー移動高

\begin{tabular}{|c|c|c|c|}
\hline & $\begin{array}{c}\text { 表 } \\
(\mathrm{mm})\end{array}$ & $\begin{array}{c}\text { 裏 } \\
(\mathrm{mm})\end{array}$ & $\begin{array}{c}\text { 平 均 } \\
(\mathrm{mm})\end{array}$ \\
\hline $\begin{array}{l}\text { 圭り鈑 } \\
\text { ヘックス } \\
\text { テー }\end{array}$ & 691 & 485 & 588 \\
\hline
\end{tabular}

スタート後取外して目荃をした。高さ方向ては爐頂部 にて爐體と擁壁間に龜裂を生した。バックステーと爐 體アーモアプレート間のこり鈑は有效てはすつたが, それてもステー自身可成り上方飞持ち上けられた。乾 燥後に於ける則定結果は第 11 表の通りてある。又膨
脹の總計を厳めると第 12 表の通りてある。

以上乾燥作業に從事した延人員は第 13 表の通り てある。職工は二交代制て，此の內焚方は煙道に 2 人て，爐體の方は最初は 1 人 5 篦持となし，順次缊

\section{第 12 表 膨 脹 總 計}

\begin{tabular}{|c|c|c|c|c|c|c|}
\hline & 厚長 & 爐頂 & 爐腹 & 爐底 & 平均 & 膨脹率 \\
\hline & 12,336 & 102 & 159 & 116 & 126 & $102^{\%}$ \\
\hline & 原長 & 表 & 中 & 㐮 & 平圴 & 膨脤率 \\
\hline 長 & 63,730 & 166 & 160 & 162 & 163 & 026 \\
\hline $\begin{array}{l}\text { 高 } \\
(\mathrm{mm})\end{array}$ & 9,980 & 122 & 137 & 134 & 131 & 131 \\
\hline
\end{tabular}

第 13 表 乾燥使用人員

\begin{tabular}{|c|c|c|c|c|}
\hline & & 凐 $(\Lambda)^{\text {道 }}$ & $\frac{\text { 爐 }}{(\Lambda)^{\text {體 }}}$ & $\begin{array}{l}1 \text { 日本均 } \\
\text { (人) }\end{array}$ \\
\hline \multirow{6}{*}{ 職工 } & ，役付 & - & 244 & 21 \\
\hline & 焚方 & 73 & 6,099 & 525 \\
\hline & 測定 & - & 748 & 64 \\
\hline & 切換 & - & 232 & 20 \\
\hline & 科量 & - & 224 & 19 \\
\hline & 計 & 73 & 7,547 & 64.9 \\
\hline \multirow{3}{*}{ 人夫 } & (運搬 & - & 885 & 77 \\
\hline & 雜 & - & 1,585 & 136 \\
\hline & (計 & - & 2,470 & 213 \\
\hline 合 & 計 & 73 & 10,017 & 862 \\
\hline
\end{tabular}




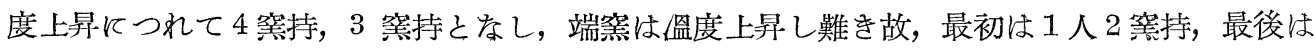
1 焦持とした。人夫の內，雜とあるは，主として灰捨作業をさしたりのてある。

\section{[5] スタート作業}

スタート作業は容易なものてなく，從來幾多の失敗を生じた例がある。特に當所は，熟練者 極めて少き故，豫めスタート作業說明書を作製して關係者酒布し，又，スタート前全員にて 豫行演晳を行ひ萬全を期した。

作業は次の如き順序て行つた。

集氮管及び吸氯管內坒気追出 軲燥栓取付

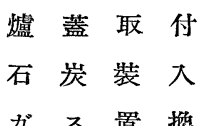

假 㗏 取 壤

ガ 又置換

元來スタート作業中危險をる事は多々あるが，其の最大のものはガスの爆發てある。コーク スガス一容に對して空军約 4〜14倍倱したものに，火氣を接近する時は爆發を起す。此の意味 より集氣管及ひ吸気管等火㲵に近き部分のものは豫め空氣を不燃性ガスにて置換し，是とコー クスガスとをさらに㯰換さすのが安全と考へられ，一般に蒸氣を通晾が、當所にては大型ス トーウ 2 臺を爐の兩端にて焚き，廢ガスを集気管の兩端より送大した。是は廢ガス中の炭酸方 ス6〜10\%をる故, 吸気管末端にて分析し其の完全に置換したか否かを知り得る。スタート當日 午前 6 時 30 分より焚き出し! 吸氣管末端にて炭酸ガス量 $64 \%$ てむつた。午前 7 時より焚口 を密閉し,乾喿栓の取付を行つた。作業順序は 3 の順に開始し, 5 本置きに 3〜8〜 13 と行つた。

假盧取壞しは，前壁梀瓦を壞し，前垂鐵板にて火熱を防ぎつ小內部庲瓦を取り出し，表は消 火車に，裹は押出機プラットに投け下し，終りをるものは爐蓋を取付け目荃をなす。斯くて5 垐終了せる時石炭を順次裝入する。石炭は水分少き時は煤を生じパイプを詰らす恐れがあり， 又多い時は爐缊を低下さすのて，當所にては $10 \%$ とした。集攻管中には巳に不燃がスが充滿 せる故，直ちに上景管と集军管の連絡を行つた。

午後 4 時 30 分裝大 10 窯を終りをる時，排送機の運轉を開始してガスを通した。硫安工 場はバイパスを通し，一旦最終伶却器後より放散し，分配管に通し，其の末端より放散させ る。爆發試驗の後, 午後 5 時 40 分飞坫火作業を開始した。分配管內のガス壓水桂 $15 \mathrm{~mm}$, フリニ一內缊度 $865^{\circ} \mathrm{C} て$, 合圖に依りコ,クを開き, 䤄穴より點火の有無を調へて, 順次, 次の空に移る。點火は極めて順調に行き，坫火棒を用ひた窒は一つもをく，端窯に至るむて完 全に點火した。

以上作業時間は第 14 表に示す通りて，14 日午前 3 時 39 分石炭裝入を最後として，全く 終了した。

14 日午後 4 時牛最初の羙出しを行つた。此の作業の間, 機杫類の故障は勿論, 小爆發一つ なく, 負傷者も亦 1 名もなく, 全く豫定の順序通り完了した事は, 當所として喜び堪へねb のてある。作業從事した人員は第 15 表の如くてある。 
第 14 表 スタート作業行程

\begin{tabular}{|c|c|c|}
\hline & 始 & 終 \\
\hline 集氣管贫氣迕出 & 第 1 日午前 6.30 & 第 1 日午後 2.50 \\
\hline 乾燥 栓取付 & 7.00 & 第 3 日午前 1.29 \\
\hline 假 爐 取 壊 & 7.28 & 2.16 \\
\hline 爐 蓋 取 付 & 8.15 & 236 \\
\hline 石炭裝 入 & 第 1 日午後 1.25 & 3.39 \\
\hline カ 入 置 換 & 1.30 & 第 1 日午後 5.30 \\
\hline 點 & 5.40 & 第 2 日个前 200 \\
\hline 押 & 第 3 日午後 4.00 & $\longrightarrow$ \\
\hline
\end{tabular}

第 15 表 スタート作對

\begin{tabular}{|c|c|c|}
\hline 作＼cjkstart業 & 人 $($ (人) & 備 \\
\hline 方 & 78 & \\
\hline 乾 燥 栓取 付 & 21 & 煉 瓦 工 \\
\hline 假 爐 取 壊 & 180 & \\
\hline 雔 物 處 理 & 160 & 人 夫 \\
\hline 爐 蓋 取 付 & 92 & 工作上, 它上 \\
\hline 石炭裝 大 & 24 & \\
\hline 力 又 置 換 & 53 & 工作工を含む \\
\hline 點 & 38 & \\
\hline 分 析, 测 定 & 28 & \\
\hline 計 & 674 & \\
\hline
\end{tabular}

終りに，御呚導を賜つた黑田泰造氏，安富多喜雄氏並に御後援下さつた日本輞管株式會社の 各位に深謝すると共に，併せて中島建設部長並に入汇定男氏の御指導に對し心より感謝する。

\section{刊 紹 介}

\section{R A Mott and R. V Wheeler 藷}

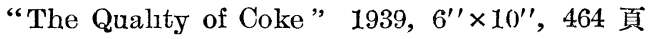

Chapman and Hall Ltd, London 欩行

本書は英國の中部コークス研究委員會 (The Midland Coke Research Committee)

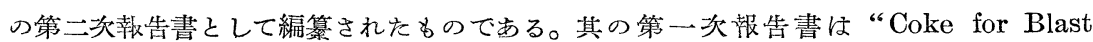
Furnaces” と題して 1930 年に發行されてるる。共に上記委員會の 研究業績を基として 編纂されをものであり，第一次報出書は 1929 年迄の 4 ケ年間の業績を集铥し，其の後 1937 年に至る 8 ケ年間の結果を本書に緾めたものである。

内容は 4 部に分孔,第 1 部 緒言, 第 2 部 コークスの性質, 第 3 部 コークスの生成, 第 4 部 コークス性質の改善 に就て迹へてるるか，本書の主项部分は第 2 部と第 3 部で ある。今, 第 2 部に於てコークスの性質として取拔つてるる項目学るに，(1)コークス の大さ，(2) コークスの構造，(3) コークスの分析，(4) コークスの比重及氮孔率，(5) コークスの枌碎性，(6) コークスの强さ，(7) コークスの反應性，(8) コークスの規恪 である。第 3 部に於てはコークス生成に當り最も重要な影響の一つは石炭の性質である坫 上り，(1）石炭の成分，(2) 石炭の熱分解，(3) 石炭の軟化性及膨脹性，（4）コークス生 成の機構 に就て进へてるる。然して製造條件がコークスの性質に及ほす影響については 第 4 部に於て，（1）石炭の粒度，(2) 製炭方法，(3) 加熱率，(4) 配合に關し記載して るるか，結論を得る迄にはな的研究を必要とする旨を迅へてるる。

因々本書著者の一人 R V Wheeler 敎授は昨年 10 月 28 日，丁度本書發行の集備中 に逝去されたので，本書が同敉授の斯界一の最後の縣物となつた譯てある。（新村） 